\title{
The Tepribaskog Assessment Model to the Violations of Maxim of Quality in Bahasa Indonesia: A Case of Residural Type of Schizophrenia with Alogia Symptoms
}

\author{
Gustianingsih $^{1}{ }^{*}$ and Dwi Widayati ${ }^{1}$ \\ ${ }^{1}$ Department of Sastra Indonesia, Faculty of Cultural Sciences, University of Sumatera Utara, Medan, \\ Indonesia
}

*Corresponding Author: Gustianingsih, Department of Sastra Indonesia, Faculty of Cultural Sciences, University of Sumatera Utara, Medan, Indonesia

\begin{abstract}
This paper describes the use of Tepribaskog model to assess the violations of maxim of quality in Bahasa Indonesia and the psycho-cognitive disorder among schizophrenia in Medan. Maxim in general has a sense of conversation, and the participants are expected to work together with friends to produce effective and efficient communication. According to Grice, in order to communicate, among participants can run smoothly, then in the utterance the participants must meet the rules that Grice calls the principle of cooperation. Grice states "is your utterance desired at the time of speech, on the basis of the objective of the agreed speech, according to the facts that occur in society and in accordance with the rules that apply in linguistics correctly". If the speech is not in accordance with the rules of language, not in accordance with the facts of linguistic truth, then the person has committed violation of the principle of cooperation. According to Videback, Shadoch and Shadoch ${ }^{[1]}$ and Cummings, the tendency of maximal offenses is caused by the impaired thinking, hallucinations, showing the withdrawal of society, the face without expression and loose association. It affects health, social life, language behavior and other negative effects. Thoughts or ideas are split and very disturbing in communicating, so the patient's speech becomes very bad. The Tepribaskog model is expected to provide a solution to reduce the negative effects of schizophrenics, which in fact can also affect all aspects of the patient's life: social interaction, emotional health, and work ability. With Tepribaskog, a long-term management strategy can be done as short as possible by nurses in hospitals, by families at home without spending money and is very efficient and done with great patience and affection.
\end{abstract}

Keywords: therapy model, maximal quality violation, schizophrenia, psychopragmatic.

\section{INTRODUCTION}

In a conversation, speakers are expected to be able to work together with their hearers to produce effective and efficient communication. Grice argued that communication among them should run smoothly and they must meet the principle of cooperation \{ see [1]). The violation of maxim among schizophrenic patients indicates that there is interruption in communication. Speech participants are expected to convey something from tangible and true to actual facts which should be supported and based on clear evidence. Grice's maxim of quality indicates 'something true and true to the real facts'.

Schizophrenia of the residural type in this paper indicates the type that shows existence of the withdrawal from society, face without expression, and loose association. It affects health, social life, language behavior and other negative effects. Loose association indicates the thought or idea that is split and very disturbing in communication, so the patient's speech becomes very bad. Meanwhile, alogia refers to a symptom that shows the tendency to speak very little and sometimes a lot but full of resignation and not meaningful.

The effects of schizophrenia on the patient can cover all aspects of the patient's life: social interaction, emotional health, and ability to work. Therefore, schizophrenia requires a long-term treatment 
The Tepribaskog Assessment Model to the Violations of Maxim of Quality in Bahasa Indonesia: A Case of Residural Type of Schizophrenia with Alogia Symptoms

strategy. In this case, the nurse plays a role in providing appropriate which is in accordance with the condition of the patient and his close relative like father, mother, child, sister and brother.

\section{METHODS}

The data collection method is both speech and hearing. The basic technique is the tapping which is carried out by tapping patient's conversation. The additional techniques are (i) see and talk, (ii) see and talk independently, (iii) recording, and (iv) note. Data analysis method involves the basic techniques of selecting certain elements (PUP) which is followed by pragmatic split capability and advanced techniques of HBB and HBS with normal speech. Furthermore, a model of experiment has been prepared for patients with schizophrenia in four psychiatric hospitals in Medan.

\section{REVIEW OF RELATED LITERATURE}

\subsection{Chomsky's Cognitive Genetic Psycholinguistics}

Chomsky is a world-class psychologist who introduced the theory of language acquisition and learning. He has drastically changed the development of psycholinguistics, from the results altered by it, then a theory about the acquisition and learning of language can be deduced from the genetic theory now known as the cognitive genetic theory. He discusses language and psychology issues, then frames it into a single frame with a cognitive form of language. Chomsky spawned the notion that the ability of human language is influenced also by his cognitive ability. His theory says that there is intervention and ability concerning memories, perceptions, thoughts, meanings and emotions that deeply put into the human psyche. When a person talks about cognitive matters in this cognitive language, then one can not deny that sometimes there is interference of genetic factors that affect a person's cognition.

Chomsky's theory includes the theory of modern psycholinguistics, which reflects the ability of reason with human knowledge, the process of acquisition and learning of language. This GeneticCognitive Theory has been based on a hypothesis called the Hypothesis of Conscience (HC) or the Innateness Hypothesis. Chomsky said that the acquisition or learning of language is based on genetic factors that belong to human beings since birth. Human brain has been genetically prepared for language. Therefore, the human brain has been equipped with a universal language structure or LAD (Language Acquisition Device). For schizophrenic person, his/her LAD is disturbed, so the automatic cognitive, perception, way of thinking, the memory of the patient will also be disturbed.

In the process of language formation, Chomsky distinguishes competence and performance. Competence is the ability of the knowledge that language users have about the language, while the performance or making the language is the implementation of the language will form a good grammar, so it can be accepted and understood both for speakers and listeners in the process of language formation. This theory is actually created for normal children, but researchers try to apply to an abnormal sufferer like this schizophrenic. Schizophrenia sufferers are indicated competence tergangggu, and will affect the performance is also disturbed. Schizophrenia sufferers are suspected of having trouble thinking, memory, perception, meaning, and emotion in his speech.

\subsection{Pragmatics}

Pragmatics is the study of the use of a language based on a particular context. The context of speech usage depends on who speaks, where the place of speech takes place, under what circumstances the speech is delivered. Social context for example has two levels, namely social high class and low class. The use of language is associated with the meaning used by speakers so that there is a relationship between pragmatik and psikolinguistik. The thoughts and speeches that focus on psycholinguistic studies are concerned with the meaning of the language used in speech acts. Concentration with the type of speech conveyed to the context of the utterance equally understood fellow communicators with the communiqué.

Levinson who states that pragmatic pragmatics is pragmatic study of the relationship between language and context that incorporates grammatical or codified forms in language structure and the context of the same speech. Thus it can be said that language analysis can not be separated from the context because it has involved the form of grammar and form of codification in a speech language. It can also be said that pragmatics is a branch of linguistics that studies the structure of language 
externally, ie how linguistic units are internally spoken externally or involves the context of speech conveyed as communication. These two different sciences will be used to analyze this research which can be known as psychopragmatic.

\section{Data ANALYSiS}

Schizophrenic speech obtained by recording and direct recording at 4 hospitals in Medan will be analyzed psychopragmatically. Speech as below is a form of quality maximizing order, because the question "who is the teacher's mother" is answered with 'angry and bouncers'.

(1) Speech form:

Researcher : : "You try SZ1, who is the teacher's mother?"

SZ1 : "anger and bouncer".

Context of Speech:

Speech was delivered by schizophrenic patient with initials SZ1 (45 years) on the hospital terrace at a relaxed time, during the day, and the patient in a calm and restrained state.

Speech (1) above is a form of maximal quality violation, because SZ1 says that "the teacher's mother is angry and the bouncer". The true fact is 'mother teacher' is a hero without service, a hero who prepares his students to be a smart, useful scholar. Nation-generation educator, classroom instructor or at home school (KBBI). Patient delivered the above sentence quietly expressionless, his face flat, and said again: yes I am what, I scolded the teacher continued, I was hit with rollers. I was told to face I failed. I'm suffering. My life is tortured. I would rather die, mom ...

The PSZ1 tutorial indicates a maximal quality violation and a severe psychopragmatic offense. PSZ1 can not understand that the old events when he was in junior high school had a very sad and miserable event, assuming all the same teachers would scold him at any time and would beat him at any moment. PSZ1 can not understand that the person who is scolded is only the person who made a mistake, if the person doing the right thing would not be scolded. As a resuscitative schizophrenic patient, it turns out that PSZ1 has severe thinking disorder, has no positive motivation to understand real life situation and condition. Negative Alogia symptoms that PSZ1 has, making this patient has no motivation at all, his life resigned and felt helpless.

Tepribaskog offered in this type of patient is:

"You are a good girl (10X) repeated, you must be successful (10x) repeated, After this you are smart, you can answer all teacher questions, Master is hero (10x) repeated, once again "hero", "Merciful" to his students. You are a Master's disciple who can be smart at times. You will be loved by the teacher very well".

This "..." sign is repeatedly referred to PSZ1, in order to be remembered by the patient that a teacher is a "good and loving hero" it is of paramount importance, this will be remembered in PSZ1's longterm memory. "You are a good girl (10X) repeated, you must be successful (10x) repeated, After this you are smart, you can answer all teacher questions, is to provide long-term memory that someday she Well, the girl to be successful, the girl who will be smart if studied diligently and able to answer teacher questions.

PSZ1 : I'm a good girl, I'm a smart girl, I'm successful, I must be loved by teacher, teacher is good. Teacher is a hero (pause), then he looked at me .. teacher hero?

Researcher : yes "you must be definitely smart".

PSZ1 : smiling and jumping up and down saying "I must be smart", "I must be good". For the initial stage, PSZ1's speech has a positive expectation, hopefully he recovers and fulfills positive motivation.

Psychologically, there are several factors of the incidence of schizophrenia in humans. The first factor is genetic factors, namely the existence of first-degree relatives such as parents (50\% have the same genes), then on second-level relatives such as uncle and aunt (25\% have the same genes). The risks of schizophrenia as mentioned above are $6 \%$ and $2 \%$, respectively. The second factor, namely the 
environment. Environmental factors are associated with the onset of schizophrenia, such as the environment of residence. Living in an urban or urban environment during childhood or adulthood consistently seems to double the risk of schizophrenia. Third factor, ie social factors such as social isolation and immigration that impact social difficulties, racial discrimination, family dysfunction, unemployment, and poor housing conditions, and ill-treatment of the environment. The fourth factor is the use of drugs.

A number of drugs are associated with the onset of schizophrenia, including cannabis, cocaine, and amphetamines. Most people with schizophrenia are users of drugs or alcohol in excess. People who are healthy even if using drugs or alcohol excessively, indicating a severe thinking disorder, especially people with schizophrenia that already has the initial characteristics of "thinking has always had a bad prejudice in others, and rarely have prejudice both for myself and people (Gustianingsih) ${ }^{[2]}$ ).

Many of the psychological mechanisms involved in the growth and development of schizophrenia. Cognitive impairment has been identified in people who are diagnosed or at risk of schizophrenia, especially in stressful situations or confusing situations. Specific symptoms that appear one of them is the loss of memory and there is incoherence (chaotic mind) spontaneous language disorder occurs such as repeated use of sentences so that the partners said do not understand the intent or desire of the schizophrenic so it is evident that all levels of language to be disturbed as well With their social interaction in the language with the surrounding environment.

(2) Speech form:

Researchers : Do you know President Joko Widodo?

PSZ2 : Our first President is .... a skinny, not big, artisan president who digged the ditch

(Suddenly) : I could be the president. Just dig the trenches ..... want to eat. Nice ... the tailbreaks ... want to grab a nice car, living by digging. Ditch ... ha ... ha ... out the president's car. President ... my president ... me President ... Only dig the ditch.

Context of speech:

Speech delivered by the researcher to a schizophrenic whose initials are PSZ2 in a nursing room with a nurse. At that moment the patient was sitting stunned with a blank look with the doctor's duty.

In plain view of data (2) above indicates that PSZ2's speech clearly violates the maxim of quality that is "President Joko Widodo" is not the first president but the seventh president of Indonesia. The first President of RI was "Soekarno", the second "Soeharto", the third "BJ. Habibie", the fourth "Aburrahman Wahid (Gusdur)", the fifth "Megawati Soekarno Putri". The sixth was "Susilo Bambang Yudhoyono", and the seventh is "Joko Widodo". The facts say PSZ2 is misinformed about the president of RI. This schizophrenic sufferer conveys as much information about the president but can be said the information is meaningless. It is impossible for a president's job to be "a trench match. Want a car to stay matches ditch, then get the car. It is impossible and meaningless. It may be true that the president of 'Blusukan', but not the ditch matches then gets what he wants.

The Tepribaskog models offered on PSZ2 and their families are:

"Dear Father, you are a" hard worker "(10x) and must be repeated, With your hard work you can become a President. The President is the head of state who leads a great country, his job is not the trench matches. On television he looks to the villages and it is called "" blusukan ", not the repeated trenches (10x). Remember "Father of kind people (10x) keep repeating, you must heal (10x) repeatedly, you have to work again, work hard (10x).

Schizophrenia is a very common mental illness. The Royal College of Psychiatrists in the UK says that one in 100 will suffer from schizophrenia, if the attitude of life and the power of the soul / mind are out of balance. Schizophrenic patients are more common in men than in women. This happens to have something to do with the very different male and female brain structures. Male brain structure is larger but thinner, while the female brain structure is smaller but thicker, so the power of thinking is more directed at women. McGrath ${ }^{[}$and clinical psychologists say the 4: 1 male and female ratio of schizophrenia is also common among migrants and people living in urban areas. The age at the onset of the outbreak of the disease also differs between men and women, men earlier suffer from 
The Tepribaskog Assessment Model to the Violations of Maxim of Quality in Bahasa Indonesia: A Case of Residural Type of Schizophrenia with Alogia Symptoms

schizophrenia than women. The negative effects of this disease are the occurrence of social interaction interference and interruption of speech on level 1-3.

Mental disorders that occur in people with schizophrenia vary from each other. This type of disorder can occur in the mind, can also occur in feelings, or on very dominant behavior until the very abstract is not clearly visible. Before a person is sick, in general the patient already has certain personality traits. The personality of the patient before the illness is called pramorbid personality that is often described as being suspicious, silent, elusive, preferably withdrawn and aloof and eccentric (unique). Mental disorders Schizophrenia usually begins to appear in adolescence or young adulthood (before age 45). A person is said to be suffering from schizophrenia if the course of his illness has shown symptoms of a mind disorder lasting for six months.

This Tepribaskog is very well applied to this schizophrenic. Therapy sepertin this done inspired by CBT therapy ever developed by Aaron Bech and Albert Ellis which has been running since the 1960s. Aaron Bech and Albert Ellis are motivators and psychotherapists, especially cognition therapy in America. Aaron Bech's CBT only deals with cognitive only, while the model employed in this study is a collaborative form of cognitive, emotional and language skills. This Tepribaskog is designed to overcome speech / language disorders such as assertiveness, declarative, expressive/evaluative, commissive and directive disorder as well as violations of maxims in the principle of cooperation in Indonesian language. Cognitive disorders such as uncontrolled anger, excessive hatred, Sadness due to heavy pressure from around the patient, and disorder of speech situation that happened to people with schizophrenia.

This Tepribaskog may be personally applied at home by person or family of the sufferer or group as in a mental hospital or home psycholinguistic therapy. This therapy is very practical to do alone and save costs. The concept of therapy is expected to change negative language behavior and negative cognitive behavior of schizophrenic patients. This model is also useful in the world of work and personal interpersonal relationships at home and social. This model can also help develop language skills effectively within the context of speech situations. This model can also help understand others by understanding the minds of others and not just demanding to be understood by others.

When a person or a schizophrenic person is severely affected by severe family pressure that results in a person becoming angry, excessive hatred, vengeance to someone and cursing the crowd, it can be considered an irrational thing. Negative thoughts, negative anger and negative language behavior can last a long time in a person or a schizophrenic and protracted until there is no positive gap from other people and become long-term memory for people with schizophrenia. This negative behavior can be reduced if care, affection and positive language behavior is given to schizophrenics with patience and tactile form. The tactile shape can take the form of a hug, a smile, a clap, or verbally (you can, you are smart, you are strong, you are great, and you are the most successful one someday) (Gustianingsih) ${ }^{[3]}$, [4].

This model will create integrated exercises between positive thought patterns and positive language skills. The exercise can be a look at the relationship between what is being thought of about an event at that time or in the past sufferers of what language pattern is always shown to others. Psychic background and family language since the patient is still small to adult need to know well so that handling of language behavior and negative cognitive behavior can be reduced effectively and efficiently. Why Tepribaskog therapy is very effective applied to people with schizophrenia, actually what is schizophrenia?

Shadock and Shadoch say that people with special needs require (1) social acceptance and prosocial behavior to reduce strange symptoms and to perfect verbal communication and nonverbal communication; (2) It takes language remediation and academic remediation for cognitive maturity; (3) Patients with language disorders with mental retardation require behavioral intervention in accordance with the intellectual sufferers to trigger socially acceptable schizophrenia and self-care skills. In addition, families should provide counseling, education and behavioral guidance advice considered as drug substitutes; (4) Structured classroom exercises combined with behavior and this is the most effective treatment for most schizophrenics; (5) rigorous exercise of the family as the concept and skill of behavioral modification and profitability in the language (broca), cognitive and social areas and behaviors. Schizophrenic sufferers need a structured, integrated and accurate program 
and most likely is a daily program done as much as possible; (6) communication with appropriate techniques should be done correctly between therapy with the participant or family who have received the facility from the home therapist.

Language disorders and violations of this principle of cooperation need to get the attention of many parties for the handling and management of language and behavior Schizophrenic patients can be overcome as soon as possible and not too late. It was once said by Brebion et al. ${ }^{[5]}$ in the International Psychiatry Journal entitled Abnormal Functioning of The Semantic Network in Schizophrenia patients with thought disorganization an exemplar production Task. It tells the story of how schizophrenics produce speech without understanding the meaning of the utterance. The linguistic semantic network can not be organized in thought. What is in the mind of the patient sometimes does not have a good relationship with the utterance produced. The function of nouns, verbs and descriptions in sentence utterances are not understood by the sufferer, so it is said that the sentence speech produced is not normal.

Salavera and Puyuelo said in the journal International Audiologia entitled Semantic and Pragmatic Aspects in Person with Schizophrenia and stated that Schizophrenia sufferers have a level of language structure that can not be compromised and are at the lowest level compared with the general public, especially in the semantic and pragmatic fields. ${ }^{[6]}$ The linguistic relationship of the schizophrenic is present but in improper conditions when speaking to others. Very need special handlers so this patient can be accepted by the general public.

Different from the opinion of Champagne-Lava and Stip in the International Neurolinguistic journal Pragmatic and Executive Dysfunction in Schizophrenia, the Schizophrenic sufferers do not understand the function of pragmati in speech. ${ }^{[7]}$ Can not understand the function of speech context, formal or informal situation. He also said that the patient is always treated late already in a chronic condition, so the handling is very long. Society should be more observant in dealing with health problems of the mind in order to avoid misunderstanding in dealing with schizophrenia. The research and model of Tepribaskog conducted in the study seems to provide enlightenment to deal with language disorder and violation of cooperative principles in Indonesian speech that no other researcher has ever done.

Cognitive deficits and language behaviors indicate that Tepribaskog is indispensable for Schizophrenic Patients and their families. This has been done by Linscott in his research saying that in schizophrenia, pragmatic weakness is associated with cognitive deficits. ${ }^{[8]}$ Linscott examined the association between pragmatic language attachment, mental disorders and general cognitive decline in twenty schizophrenic patients. The Profile of Pragmatic Impairment in Communication (Haye et al. ${ }^{[9]}$; Linscott) was used to give scores to the subjects to determine the pragmatic weakness of language. The pragmatic weakness of language and cognitive decline are common in schizophrenic subjects. In addition, general cognitive decline allows for pragmatic language weakening. Linscott said that the pragmatic attenuation of language in schizophrenics occurs after a general cognitive decline.

\section{CONCLusions}

The principle of cooperation, especially those that occur in the maxims of speech in Indonesian language is caused by severe psychopragmatic disorders of schizophrenics. Tepribaskog is expected to provide a solution to reduce the negative effects of schizophrenics, which in fact can also affect all aspects of the patient's life: social interaction, emotional health, and ability to work. With Tepribaskog, long-term management strategies, can be done as short as possible by nurses in hospitals, families at home without spending money and are very efficient and done with great patience and affection.

\section{REFERENCES}

[1] Shadock and Shadoch .2010. Phsichology of Behavior Special Need. Fransisco: W.H. Freeman and Company.

[2] Gustianingsih. 2016. Gangguan Pertuturan Ilokusi Bahasa Indonesia Kerjasama pada Penderita Skizofrenia di kopta Medan. Hasil Penelitian Hibah Bersaing Tahun I. 
The Tepribaskog Assessment Model to the Violations of Maxim of Quality in Bahasa Indonesia: A Case of Residural Type of Schizophrenia with Alogia Symptoms

[3] Gustianingsih. 2014. Gangguan Fonologis Bahasa Indonesia pada Anak Autistic Spectrum Disorder di Kota Medan ( Kasus Anak Usia 7-10 Tahun). Hasil Penelitian Hibah Bersaing.

[4] Gustianingsih. 2015. Gangguan Fonologis Bahasa Indonesia pada Anak Autistic Spectrum Disorder di Kota Medan ( Kasus Dewasa Usia 17-24 Tahun). Hasil Penelitian Hibah Bersaing.

[5] Brebion G. and Stephan Ottoc. 2012. "Abnormal Functioning of The Semantic Network in Schizophrenia Patients With thought disorganization An Exemplar Production Task". dalam Jurnal International Psychiatry.

[6] Salavera C, Puyuelo,M. 2010. "Semantic and Pragmatic Aspects in Person with Schizofrenia." International Jurnal Audologia.

[7] Champagne-Lava M, Stip E. 2010. "Pragmatic and Executive Dysfunction in Schizofrenia". Dalam International Neurolinguistic Jurnal Vol.121.

[8] Linscott. 2005. Profile of Pragmatic Impairment in Communication . Cambridge: Cambridge University Press.

[9] Haye, et.al. 2004. Profile of Pragmatic Impairment in Communication of Schizofrenic and Special Need. New York : WH Company.

Citation: Gustianingsih \& Dwi Widayati "The Tepribaskog Assessment Model to the Violations of Maxim of Quality in Bahasa Indonesia: A Case of Residural Type of Schizophrenia with Alogia Symptoms" International Journal of Humanities Social Sciences and Education (IJHSSE), vol 4, no. 11, 2017, pp. $78-84$. doi:http://dx.doi.org/10.20431/2349-0381.0411009.

Copyright: () 2017 Authors. This is an open-access article distributed under the terms of the Creative Commons Attribution License, which permits unrestricted use, distribution, and reproduction in any medium, provided the original author and source are credited. 